\title{
Effects of drying temperature on drying kinetics and eurycomanone content of Eurycoma longifolia roots
}

\author{
${ }^{1,2 *}$ Hada Masayu, I., ${ }^{1}$ Pin, K.Y., ${ }^{2}$ Mohd. Nordin, I., ${ }^{2}$ Rabitah, Z. and ${ }^{1}$ Mohd. Radzi, A. \\ ${ }^{1}$ Natural Products Division, Forest Research Institute Malaysia (FRIM), 52109 Kepong, Selangor \\ ${ }_{2}^{2}$ Process and Food Engineering Department, Universiti Putra Malaysia (UPM), 43000 Serdang Selangor
}

\section{Article history: \\ Received: 12 July 2017 \\ Received in revised form: 7 \\ August 2017 \\ Accepted: 8 August 2017 \\ Available Online: 10 \\ August 2017}

\section{Keywords:}

Convection oven drying,

Eurycoma longifolia,

Eurycomanone,

Empirical modeling

\section{DOI:}

http://doi.org/10.26656/

fr.2017.6.112

\begin{abstract}
In this study, the effects of temperature on drying kinetics and eurycomanone content of Eurycoma longifolia roots were investigated to determine the optimum temperature for drying of this herb. The roots were subjected to drying temperatures of 40, 50, 60 and $70^{\circ}$ C. The drying kinetics data indicated that the drying rate increased with increase in temperature but decreased with time. The drying process took place in the falling rate period. Three established thin layer drying models include Page, Midili and Logarithmic were employed to describe the drying process. The Midili model was found as the best fitting model in representing the process. The quality of the products was evaluated by comparing the content of its active compound, eurycomanone, quantified using an ultra performance liquid chromatography (UPLC). The fastest drying process was achieved at $70^{\circ} \mathrm{C}$, but UPLC results showed that the product suffered at $18 \%$ reduction in eurycomanone content as compared to the control. Based on the findings of this work, the optimum drying temperature for E. longifolia roots is $60^{\circ} \mathrm{C}$.
\end{abstract}

\section{Introduction}

Eurycoma longifolia is a medium-sized tree growing to a height of about $10 \mathrm{~m}$. The plant is mostly found as an under-storey growth of lowland forests in Peninsula Malaysia and other Southeast Asian Regions (Ang et al., 1995). In Vietnam, it is the tree "that cures a hundred diseases" but in Malaysia, it is better known for its aphrodisiac properties (Chuah et al., 2007). Eurycoma longifolia can be harvested starting 5 years after cultivation (Radzi et al., 2005).

The plant is traditionally used as a general tonic, after childbirth tonic, aphrodisiac, antidotal, antihypertensive, antipyretic, antituberculotic, antivenous, vermifuge and febrifuge (Jaganath and $\mathrm{Ng}$, 2000). The plant part that is found with high medicinal properties is its root which is yellowish with strong bitter taste. Plant extract from the roots also used traditionally for enhancing testosterone levels in men and reducing blood pressure, fever and fatigue mainly due to the presence of eurycomanone (Bhat and Karim, 2010). Eurycomanone is a plant quassinoids derived from $E$. longifolia roots. It is referred as one of the commercial potential chemicals for $E$. longifolia other than eurycomanol and eurycomalactone (Jaganath and $\mathrm{Ng}$, 2000). Biological studies have shown that eurycomanone also possesses antimalarial activity against Plasmodium falciparum (Ang et al., 1995).

Drying is a process of removing moisture from products to reduce weight and volume that will facilitate packaging, storage, and transportation. Drying also helps in improving product stability during storage by preventing microbial contamination caused by the presence of moisture content. Convection oven drying is a widely-used drying method in the local herbal industry due to its simple operation. Optimization using this method is essential to ensure products are dried appropriately to minimize degradation. Previous studies conducted on cocoa had revealed that the use of high temperature is often compromised by degradation or loss of quality of the product (Alean et al., 2016). Material dried in a controlled way may contribute to the more uniform distribution of the moisture content during drying (Kowalski et al., 2005).

A number of established drying models have been developed to explain the convective drying kinetics of various agricultural products for use in design, 
construction, and control of drying systems (Soysal et al., 2006). Page (Sobukola and Dairo, 2007), Midili (Midili et al., 2002) and Logarithmic (Pin et al., 2009) equations are frequently used to describe drying kinetics of various herbal materials such as rosemary leaves (Arslan and Musa Özcan 2008), parsley leaves (Akpinar et al., 2006), ginger (Nema et al., 2013) and betel leaves (Pin et al., 2009). Based on their application to herbs, the three drying models were also used to describe the drying characteristics of E. longifolia in the present study.

Many studies have reported on the chemical markers and bioactivity of E. longifolia but what absent in the literature is on the optimization of drying process from this famous herb. A major consideration in herbal drying is the preservation of the chemical compounds, which mostly heat sensitive because these compounds contribute to the beneficial bioactivities of herbs. In this study, eurycomanone, as an active compound, was selected as the quality indicator for E. longifolia roots. The content of eurycomanone was determined using ultra-performance liquid chromatography (UPLC). The best drying temperature of E. longifolia roots based on its quality and drying time was selected.

\section{Materials and methods}

\subsection{Materials}

Fresh plant of Eurycoma longifolia was collected from cultivation plot at Bukit Hari of Forest Research Institute Malaysia (FRIM), Kepong. The selected part of the plant was the root to be used in the experiment. The collected samples were cleaned from dirt using tap water, rinsed, chopped and then kept in polystyrene container before being transported to the laboratory. Initial moisture content of the roots was $63.0 \pm 2.9 \%$ (wet basis, wb) measured before each experiment using calibrated Halogen Moisture Analyzer (Model AND MS70, Japan).

\subsection{Experimental design}

The convection oven dryer (UFE 500 type, Memmert, Germany) used in this study consists of four main components namely heating elements, drying trays, fan and temperature control button. The drying process was operated at four selected temperatures of 40, 50, 60 and $70^{\circ} \mathrm{C}$. Fan speed was kept constant at $1.0 \mathrm{~m} / \mathrm{s}$.

Approximate weight of $0.500 \mathrm{~g}$ fresh sample was distributed uniformly as a thin layer on an aluminum tray with square openings of $14 \times 8 \mathrm{~cm}$. Weights loss from the samples was measured by weighing the sample outside the drying chamber periodically using electronic balance (Model AND FX-1200i, Japan). The weighing procedure took not more than $30 \mathrm{~s}$. Weights were recorded every 10 minutes until the equilibrium moisture content was reached. Data was taken for the calculation of moisture content during the whole drying process. Each drying experiment was done in triplicate. Final product moisture content $\left(w_{b}\right)$ was determined using a Halogen moisture analyzer (Model AND MS-70, Japan).

\subsection{Analysis of drying data}

\subsubsection{Mathematical modelling}

The free moisture versus drying time graphs was plotted for each of the experiment. Moisture content (dry basis) of the sample was described by the percentage equivalent of the ratio of the weight of water to the total weight of the dry material. It was calculated by using equation (1) (Ramaswamy and Marcotte, 2006):

$$
\text { Moisture content }=\frac{M}{S} \times 100
$$

Where $M$ is the content of moisture and $S$ is the content of solid.

\subsubsection{Drying curves}

The drying rate versus free moisture graph was plotted for each of experiments. The drying rate of the sample was calculated using equation 2 (Akpinar and Bicer, 2003):

$$
\text { Drying rate }=\frac{M_{(t+d t)}-M_{t}}{d t}
$$

Where $M_{(t+d t)}$ and $M_{t}$ are moisture content at $t+d t$ (g water / g dry solid) and moisture content at time $t$, respectively and $t$ is drying time (min).

\subsubsection{Modelling of drying process}

Experimental data obtained were fitted to the three well-known thin layer drying models given in Table 1 . These models require the calculation of dimensionless moisture ratio, which is given by equation (3) (Sacilik, 2007):

$$
\text { Moisture ratio }=\frac{M-M_{E}}{M_{0}-M_{E}}
$$

where $\mathrm{M}, \mathrm{M}_{\mathrm{e}}$ and $\mathrm{M}_{0}$ are the moisture content at any time, the equilibrium moisture content and the initial moisture content, respectively.

The correlation coefficient $\left(\mathrm{R}^{2}\right)$ was the primary criterion for selecting the best model to describe the drying curves. In addition to $\mathrm{R}^{2}$, root mean square error (RMSE) analysis was used to determine the goodness of 
the fit. The higher the value of $\mathrm{R}^{2}$ and the lowest values of RMSE, the better the goodness of the fit (Oke and Workneh, 2014). They were calculated using equation (4) and (5) (Pin et al., 2009):

$$
\begin{aligned}
& R^{2}=1-\left[\frac{\sum_{i=1}^{N}\left(M R_{\text {expi }}-M R_{p r e, i}\right)^{2}}{\sum_{i=1}^{N}\left(M R_{\text {expi }}-M R_{\text {exp }}\right.}\right] \\
& R M S E=\left[\frac{1}{N} \sum_{i=1}^{N}\left(M R_{\text {exp }, i}-M R_{p r e, i}\right]^{1 / 2}\right.
\end{aligned}
$$

where $M R_{\text {exp, } i}$ is the $\mathrm{i}^{\text {th }}$ experimentally observed moisture ratio, $M R_{\text {pre }, i}$ is the $i^{\text {th }}$ predicted moisture ratio, $\mathrm{N}$ the number of observations.

\begin{tabular}{|c|c|c|}
\hline $\begin{array}{c}\text { Model } \\
\text { name }\end{array}$ & Model & Reference \\
\hline Midili & $\mathrm{MR}=\mathrm{a} \exp \left(-\mathrm{kt}^{\mathrm{n}}\right)+\mathrm{bt}$ & Midili et al. (2002) \\
\hline Page & $\mathrm{MR}=\exp \left(-\mathrm{kt}^{\mathrm{n}}\right)$ & $\begin{array}{l}\text { Sobukola and } \\
\text { Dairo (2007) }\end{array}$ \\
\hline Logarithmic & $\mathrm{MR}=\mathrm{a} \exp \left(-k \mathrm{t}^{\mathrm{n}}\right)+\mathrm{b}$ & Pin et al. (2009) \\
\hline
\end{tabular}

Table 1. Mathematical models applied to the drying process.

\subsection{Chemical analysis}

Ultra Performance Liquid Chromatography (UPLC) was used for the qualification and quantification of eurycomanone from EL roots. An Acquity ${ }^{\circledR}$ BEH C18 column $(2.1 \times 150.0 \mathrm{~mm}, 1.7 \mu \mathrm{m}$ particle size $)$ was used as stationary phase. The mobile phase comprised of $0.1 \%$ formic acid and 100\% acetonitrile. Table 2 shows the change of mobile phase during the analysis. The wavelength at $244.4 \mathrm{~nm}$ was chosen because the detection of eurycomanone was sensitive at that wavelength.

Table 2. The mobile phase change in UPLC analysis.

\begin{tabular}{cccc}
\hline $\begin{array}{c}\text { Time } \\
(\mathrm{min})\end{array}$ & $\begin{array}{c}\text { Flow rate } \\
(\mathrm{ml} / \mathrm{min})\end{array}$ & $\begin{array}{c}0.1 \% \text { Formic } \\
\text { Acid (\%) }\end{array}$ & $\begin{array}{c}100 \% \\
\text { Acetonitrile (\%) }\end{array}$ \\
\hline 0 & 0.20 & 90 & 10 \\
2 & 0.25 & 85 & 15 \\
5 & 0.30 & 75 & 25 \\
10 & 0.25 & 60 & 40 \\
12 & 0.20 & 90 & 10 \\
\hline
\end{tabular}

A few steps are involved in the preparation of crude extracts of E. longifolia roots. First, the dried materials were ground using the pulverizing machine (Model RT08, $25000 \mathrm{rpm})$. Then, the dried E. longifolia roots were mixed with distilled water in 1:10 ratio (Radzi et al., 2005). Next, the mixture was sonicated using a sonicator (Model 2510, Branson, USA) for 60 minutes at $37^{\circ} \mathrm{C}$ to speed up the extraction of the phytochemicals. After sonication, the extracts were filtered to remove the solid particles. The filtrate was injected into the UPLC for analysis to determine its chemical profiles and concentrations of eurycomanone, respectively.

\section{Results and discussion}

\subsection{Drying kinetics}

Figure 1 shows the changes in moisture against time at $40,50,60$ and $70^{\circ} \mathrm{C}$ of the convection oven drying process. It was found that the drying time for $40,50,60$ and $70^{\circ} \mathrm{C}$ was $70,60,40$ and 30 minutes respectively. Drying at $70^{\circ} \mathrm{C}$ was 40 minutes shorter than at $40^{\circ} \mathrm{C}$ indicates that higher drying temperature resulted in shorter drying times. This was because of a larger driving force for heat transfer at $70^{\circ} \mathrm{C}$ as compared with at lower temperatures. A similar trend was also reported by other researchers (Akpinar et al., 2006; Sacilik, 2007; Pin et al., 2009; Jaloszynski et al., 2009; Arslan and Musa Özcan, 2010; Gupta et al., 2013; Arabi et al., 2016)

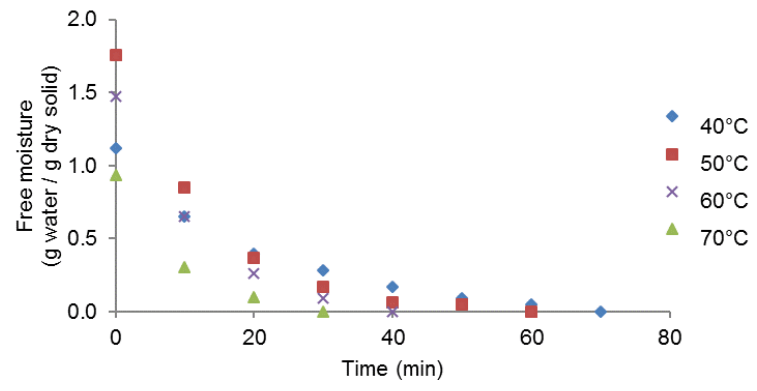

Figure 1. Drying curves of E. longifolia roots dried at 40 to $70^{\circ} \mathrm{C}$ using convection oven

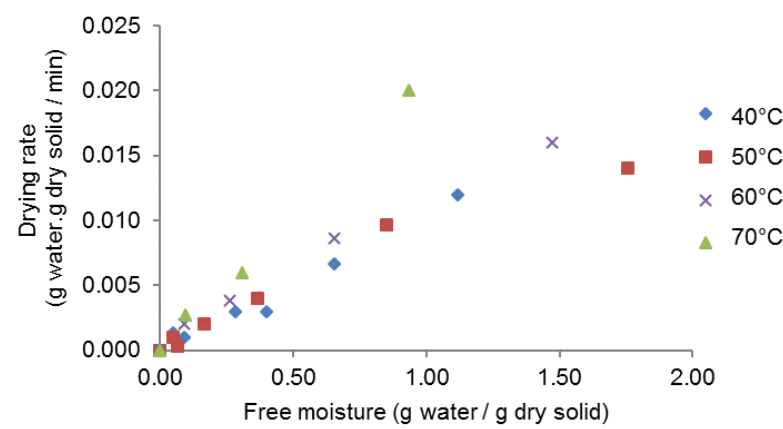

Figure 2. Drying rate curves of EL roots dried at 40 to $70^{\circ} \mathrm{C}$ using convection oven

Figure 2 represents a set of drying rate curves of $E$. longifolia roots dried using the convection oven at 40 , 50,60 and $70^{\circ} \mathrm{C}$. In view of the figure, the entire drying process showing stages of falling rate period. The drying rate of the roots dropped rapidly at the first stage of falling rate period. At this stage, the rate of drying depends greatly on the mechanism by which the moisture 
Table 3. The values of $\mathrm{R}^{2}$, RMSE and drying constant for thin-layer drying models from convection oven of E. longifolia roots

\begin{tabular}{|c|c|c|c|c|}
\hline Model & Drying temperature $\left({ }^{\circ} \mathrm{C}\right)$ & Constant & $\mathrm{R}^{2}$ & RMSE \\
\hline \multirow{4}{*}{ Midili } & 40 & $\begin{array}{l}\mathrm{a}=0.9994, \mathrm{k}=0.0670 \\
\mathrm{n}=0.8943, \mathrm{~b}=-0.0004\end{array}$ & 0.9870 & 0.01110 \\
\hline & 50 & $\begin{array}{l}a=1.0003, k=0.0607 \\
n=1.0780, b=-6.73 E-06\end{array}$ & 0.9976 & 0.00523 \\
\hline & 60 & $\begin{array}{l}\mathrm{a}=0.9996, \mathrm{k}=0.0584 \\
\mathrm{n}=1.1284, \mathrm{~b}=-0.0002\end{array}$ & 0.9968 & 0.00742 \\
\hline & 70 & $\begin{array}{l}\mathrm{a}=0.9998, \mathrm{k}=0.0854 \\
\mathrm{n}=1.1059, \mathrm{~b}=-0.0002\end{array}$ & 0.9953 & 0.01013 \\
\hline \multirow{4}{*}{ Logarithmic } & 40 & $\begin{array}{l}a=1.0048, k=0.0475 \\
b=-0.0162\end{array}$ & 0.9752 & 0.01540 \\
\hline & 50 & $\begin{array}{l}a=1.0103, k=0.0746 \\
b=-0.0067\end{array}$ & 0.9945 & 0.00782 \\
\hline & 60 & $\begin{array}{l}a=1.0277, k=0.0794 \\
b=-0.0238\end{array}$ & 0.9932 & 0.01077 \\
\hline & 70 & $\begin{array}{l}a=1.0178, k=0.1082 \\
b=-0.0166\end{array}$ & 0.9945 & 0.01091 \\
\hline \multirow{4}{*}{ Page } & 40 & $\mathrm{k}=0.0541, \mathrm{n}=0.9774$ & 0.9694 & 0.01710 \\
\hline & 50 & $\mathrm{k}=0.0604, \mathrm{n}=1.0798$ & 0.9975 & 0.00524 \\
\hline & 60 & $\mathrm{k}=0.0545, \mathrm{n}=1.1588$ & 0.9953 & 0.00892 \\
\hline & 70 & $\mathrm{k}=0.0794, \mathrm{n}=1.139362$ & 0.9944 & 0.01101 \\
\hline
\end{tabular}

from inside the root was transferred to the surface. At the later stage where the second falling rate period took place, the drying rate slowly decreased and approached equilibrium moisture level. The surface of the root was dried and evaporation occurred from within the solid and vapor reached the surface by molecular diffusion through the material. Higher drying rates were observed at higher temperatures. The drying rate was found maximum when the root was dried at $70^{\circ} \mathrm{C}$. These results are in agreement with earlier observations on drying of onion slices (Arslan and Musa Özcan, 2010), Acacia mangium (Nadhari et al., 2014), strawberry (Doymaz, 2008), kiwifruit (Orikasa et al., 2008) and cocoa (Hii et al., 2009).

\subsection{Modeling of drying process}

Three different thin-layer drying models namely Midili, Logarithmic and Page models were evaluated in finding the most suitable model to describe the drying process of E. longifolia roots. The models were evaluated based on RMSE and correlation coefficient $\left(\mathrm{R}^{2}\right)$. SOLVER in Microsoft Excel 2007 was used to solve $\mathrm{R}^{2}$ close to unity and the RMSE values were calculated to compare the results.

The model that best explained the drying process of E. longifolia roots is the one that gives the highest $\mathrm{R}^{2}$ and the lowest RMSE values as tabulated in Table 3. The values of $\mathrm{R}^{2}$ calculated for all the experiments were more than 0.95 and RMSE values were very low $(<0.05)$. This indicates that the selected models fit well with the experimental data. Midili model was the most suitable model to fit the drying kinetics of all temperatures studied.

The previous study on drying of poplar wood particles (Arabi et al., 2016) reported that among the eleven thin-layer models tested, Midili, Kucuk and Yapar and Henderson and Pabis models have been found to be the best models for describing the drying curve of the wood particle. Another study on drying of ginger showed that Midili model was found to be the best in describing the pulse microwave drying behavior of ginger (Nema et al., 2013). The Midili-Kucuk model with four model constants is found to be the best model for various products by researchers (Kucuk et al., 2014).

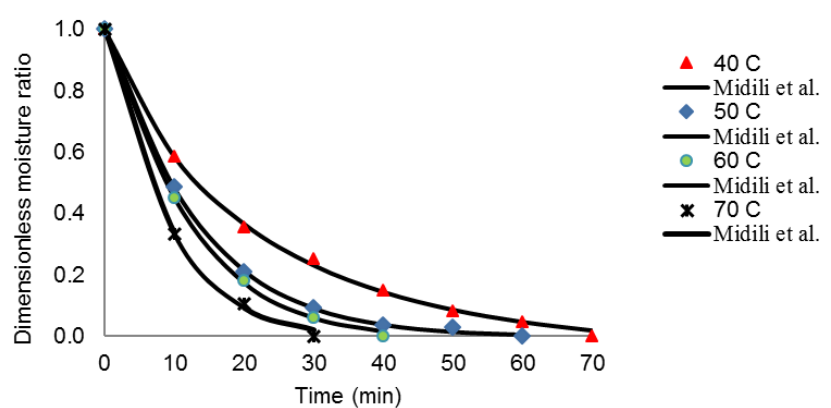

Figure 3. Comparison between the experimental data with the predicted (Midili) model

The plot of experimental data and the best-fitted model was shown in Figure 3. Based on Midili model, a temperature-and-time dependent equation for drying of E. longifolia roots for the studied temperature range was developed as follows: 
$\mathrm{MR}=\mathrm{a} \exp \left(-\mathrm{kt}^{\mathrm{n}}\right)+\mathrm{bt}$, where

$\mathrm{a}=0.9995$

$\mathrm{k}=0.0388+0.0005 *(\mathrm{~T})$

$\mathrm{n}=0.6748+0.0069 *(\mathrm{~T})$

$\mathrm{b}=-0.0005$

$\mathrm{T}=$ temperature

\subsection{Effect of drying temperature on eurycomanone content}

Figure 4 shows the effect of drying temperatures on the concentration of eurycomanone from E. longifolia roots. The control sample was referring to roots dried using natural air at room conditions of $26^{\circ} \mathrm{C}$ and $67 \%$ relative humidity. It was observed that concentration of eurycomanone was significantly higher in roots dried at $40(12.53 \mathrm{mg} / \mathrm{L}), 50(12.24 \mathrm{mg} / \mathrm{L})$ and $60^{\circ} \mathrm{C}(13.66 \mathrm{mg} /$ L) as compared to control. This observation showed that the drying process caused the increase of eurycomanone in the dried products. A similar behavior was found by Pin et al. (2009). They found that the concentrations of compounds in the fresh betel leaves were lower than leaves dried at oven temperatures of 40, 50, 60, 70 and $80^{\circ} \mathrm{C}$. Arslan and Musa Özcan (2010) also found that oven dried onion slices at $70^{\circ} \mathrm{C}$ had higher phenolic content than the fresh samples.

Drying might have accelerated the release of bound phenolic compounds during the breakdown of cellular constituents (Chang et al., 2006). A study by Deng and Zhao (2008) showed that folded cell walls and collapsed structure was visible from the microstructure of freezedried apples. In the case of drying E. longifolia roots in this present study, the increase in eurycomanone content in the dried materials might result from thermal exposure during drying that caused deformation of the cell structure of the roots and lead to the secretion of the more eurycomanone compound from the collapsed cell structure.

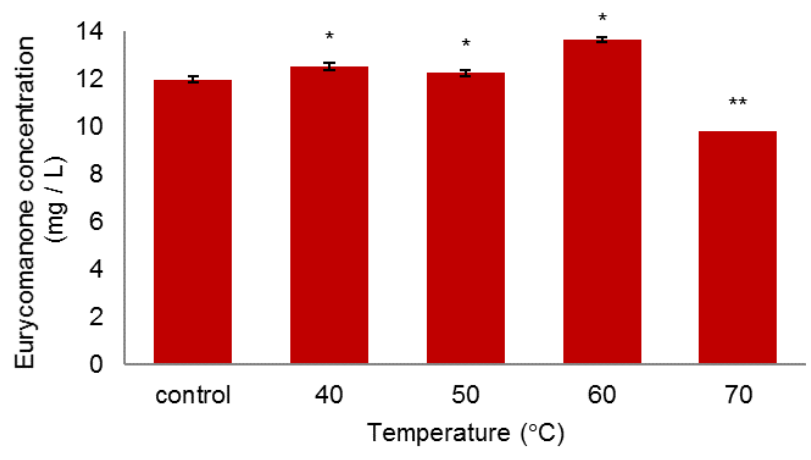

Figure 4. Eurycomanone concentration in E. longifolia roots subjected to convection oven temperatures of 40, 50, 60 and $70^{\circ} \mathrm{C}$
Eurycomanone content was found significantly lower in the roots dried at the highest temperature of $70^{\circ}$ C $(9.80 \mathrm{mg} / \mathrm{L})$ as compared to control. The roots might be affected by thermal degradation as evidence by the decreased content of eurycomanone achieved. The results suggest that the difference was small in eurycomanone content of roots dried at 40,50 and $60^{\circ} \mathrm{C}$ as compared with control sample. It may not contribute to quality change. However, the roots were affected more at an elevated temperature of $70^{\circ} \mathrm{C}$.

\section{Conclusion}

The effect of drying temperature on drying time and eurycomanone concentration was studied. The drying time could reduce as drying temperature increased from 40 to $70^{\circ}$, however, the eurycomanone concentration of E. longifolia roots reduced significantly at drying temperature of $70^{\circ} \mathrm{C}$. The eurycomanone concentration of sample dried at $60^{\circ} \mathrm{C}$ was at its highest value than that of other dried samples. Convection oven drying of $E$. longifolia at this temperature is generally recommended. Among the three thin-layer drying models that were fitted to the experimental data, the Midili model showed the best fit although all the models could satisfactorily describe the convection oven drying kinetics of E.longifolia.

\section{Acknowledgements}

The authors wish to acknowledge the support and help given by the staff of Natural Products Division, Forest Research Institute Malaysia (FRIM).

\section{References}

Akpinar, E.K. and Bicer, Y. (2003). Modeling and experimental study on drying of apple slices in a convective cyclone dryer. Journal of Food Process Engineering, 26, 515-541.

Akpinar, E.K., Bicer, Y. and Cetinkaya, F. (2006). Modelling of thin layer drying of parsley leaves in a convective dryer and under open sun. Journal of Food Engineering, 75(3), 308-315.

Alean, J., Chejne, F. and Rojano, B. (2016). Degradation of polyphenols during the cocoa drying process, Journal of Food Engineering, 189, 99-105.

Ang, H.H., Chan, K.L. and Mak, J.W. (1995). Effect of 7 -day daily replacement of culture medium containing Eurycoma longifolia Jack constituents on the Malaysian Plasmodium falciparum isolates. Journal 
of Ethnopharmacology, 49(3), 171-175

Arabi, M., Faezipour, M.M., Layeghi, M., Khanali, M. and Zareahosseinabadi, H. (2016). Evaluation of thin -layer models for describing drying kinetics of poplar wood particles in a fluidized bed dryer. Particulate Science and Technology, 6351, 1-8.

Arslan, D. and Musa Özcan, M. (2008). Evaluation of drying methods with respect to drying kinetics, mineral content and colour characteristics of rosemary leaves. Energy Conversion and Management, 49, 1258-1264.

Arslan, D. and Musa Özcan, M. (2010). Study on the effect of sun, oven and microwave drying on quality of onion slices. Food Science and Technology, 43(7), 1121-1127.

Bhat, R. and Karim A.A. (2010). Tongkat ali (Eurycoma longifolia Jack): A review on its ethnobotany and pharmacological importance. Fitoterapia, 81, 669679.

Chang, C., Lin, H., Chang, C. and Liu, Y. (2006). Comparisons on the antioxidant properties of fresh, freeze-dried and hot-air-dried tomatoes, Journal of Food Engineering, 77, 478-485.

Chuah C.H., Mok J.S.L., Liew S.L. and Ong H.C. (2007). 101 Plants to fight cancer, p. 86-87. Sarawak: Sarawak Biodiversity Centre.

Deng, Y. and Zhao, Y. (2008). Effect of pulsed vacuum and ultrasound osmopretreatments on glass transition temperature, texture, microstructure and calcium penetration of dried apples (Fuji). Food Science and Technology, 41(9), 1575-1585.

Doymaz, I. (2008). Convective drying kinetics of strawberry. Chemical Engineering and Processing, 47, 914-919.

Gupta, M.K., Sehgal, V.K. and Arora, S. (2013). Optimization of drying process parameters for cauliflower drying. Journal of Food Science and Technology, 50, 62-69.

Hii, C. L., Law, C. L., Cloke, M. and Suzannah, S. (2009). Thin layer drying kinetics of cocoa and dried product quality. Biosystems Engineering, 102(2), 153-161.

Jaganath, I.B. and Ng, L.T. (2000). Herbs: The green pharmacy of Malaysia. Kuala Lumpur: Vinpress Sdn. Bhd.

Jaloszynski, K., Figiel, A. and Wojdylo, A. (2009). Drying kinetics and antioxidant activity of oregano. Acta Agrophysica, 11, 81-90.

Kowalski, S.J., Rajewska, K. and Rybicki, A. (2005). Stresses generated during convective and microwave drying. Drying Technology, 23(9-11), 1875-1893.

Kucuk, H., Midili, A., Kilic, A. and Dincer, I. (2014). A Review on Thin-layer Drying-Curve Equations. Drying Technology, 32(7), 7577 - 773

Midilli, A., Kucuk, H. and Yapar, Z. (2002). A New model for single-layer drying. Drying Technology, 20(7), 1503-1513.

Nadhari, W.N.A.W., Hashim, R., Danish, M., Sulaiman, O. and Hiziroglu, S. (2014). A Model of Drying Kinetics of Acacia mangium Wood at Different Temperatures. Drying Technology, 32, 361-370.

Nema, P.K., Mohapatra, D., Daniel, A. and Mishra, S. (2013). Modeling pulse microwave drying kinetics of ginger. Journal of Food Research and Technology, 1(2), 46-58.

Oke, M.O. and Workneh, T.S. (2014). Convective hot air drying of different varieties of blanched sweet potato slices. Journal of Biological, Biomolecular, Agricultural, Food and Biotechnological Engineering, 8(12): 1349-1355.

Orikasa, T., Wu, L., Shiina, T. and Tagawa, A. (2008). Drying characteristics of kiwifruit during hot air drying. Journal of Food Engineering, 85, 303-308.

Pin, K.Y., Chuah, T.G., Rashih, A.A., Law, C.L., Rasadah, M.A. and Choong, T.S.Y. (2009). Drying of Betel Leaves (Piper betle L.): Quality and Drying Kinetics. Drying Technology, 27(1), 149-155.

Radzi, M.A., Ilham, M.A., Norijas, A.A., Noh, M.J. and Ghawas M. (2005). Penentuan kualiti berdasarkan kandungan kimia dan usia penanaman tongkat ali (Secara perladangan). In Chang Y.S., Vimala S., Mazura M.P. and Ong B.K. (Eds). Current trends and perspectives. Proceedings of the Seminar on Medicinal and Aromatic Plants (MAPS 2004). 20-21 July 2004, p. 279-285. Kuala Lumpur: FRIM, Kepong

Ramaswamy, H. and Marcotte, M. (2006). Food processing: Principles and applications. Florida: CRC press.

Sacilik, K. (2007). Effect of drying methods on thinlayer drying characteristics of hull-less seed pumpkin (Cucurbita pepo L.). Journal of Food Engineering, 79(1), 23-30.

Sobukola, O.P. and Dairo, O.U. (2007). Modeling drying kinetics of fever leaves (Ocimum viride) in a convective hot air dryer. Nigerian Food Journal, 25 (1), $146-154$.

Soysal, Y., Öztekin, S. and Eren, Ö. (2006). Microwave drying of parsley: Modelling, kinetics and energy aspects. Biosystem Engineering, 93, 403 - 413. 